\title{
Evaluasi Penggunaan Antibiotik pada Balita Penderita Pneumonia Rawat Inap di RSUD "Y” di Kota "X" Tahun 2016
}

\section{Evaluation of Antibiotic Use in Toddler Patients of Pneumonia at "Y" Hospital of "X" City in 2016}

\author{
Panji 'Utsman*, Hidayah Karuniawati \\ Fakultas Farmasi, Universitas Muhammadiyah Surakarta, \\ Jalan Achmad Yani Tromol Pos 1, Pabelan, Kartasura Surakarta \\ e-mail: panji_utsman@yahoo.co.id
}

Received: 18 April 2018; Accepted: 10 Juni 2020; Published: 30 Juni 2020

\begin{abstract}
Abstrak
Pneumonia adalah penyakit infeksi pada bagian parenkim paru-paru yang disebabkan oleh mikroorganisme. Terapi untuk mengobati pneumonia yaitu menggunakan antibiotik. Tata laksana terapinya perlu dipilih antibiotik yang tepat untuk mencegah resistensi bakteri dan untuk meningkatkan efektifitas pengobatan. Tujuan dari penelitian ini adalah untuk menilai gambaran dan rasionalitas penggunaan antibiotik pada pasien balita penderita pneumonia di instalasi rawat inap RSUD "Y" di kota "X" tahun 2016. Penelitian non eksperimental ini yang dilakukan secara retrospektif yang dianalisis secara deskriptif. Teknik sampling yang digunakan adalahpurposive sampling dengan menelusuri catatan rekam medik pasien balita penderita pneumonia di instalasi rawat inap RSUD "Y" di kota "X" tahun 2016 yang memenuhi kriteria inklusi. Evaluasi ketepatan dianalisis menggunakan acuan Pedoman Pelayanan Medis Ikatan Dokter Anak Indonesia tahun 2009 dan British National Formularium for Children 2011-2012 yang meliputi ketepatan indikasi, ketepatan obat, tepat pasien dan ketepatan dosis. Hasil penelitian yang melibatkan 49 pasien balita penderita pneumonia didapatkan bahwajenis antibiotik yang digunakan adalah cefotaxime $(89,80 \%)$, Ampisillin (4,08\%), Kombinasi Cefotaxime-gentamicin (4,08\%) dan Ampisillingentamicin $(2,04 \%)$. Hasil evaluasi ketepatan pemakaian antibiotik menunjukkan $100 \%$ tepat indikasi, 93,87\% tepat obat, $100 \%$ tepat pasien dan $10,20 \%$ tepat dosis.
\end{abstract}

Kata Kunci: pneumonia, balita, antibiotik, rasional

\begin{abstract}
Pneumonia was pulmonary lung disease called parenchyma caused by microorganism, Pneumonia can be cured byantibiotic to prevent the resistantof bacteria and to improve the effective of the treatment, the right antibiotic must be determining. This research purpose is to determine the accuracy of using antibiotic in toddler patients suffering pneumonia who hospitalized in RSUD " $Y$ " " $X$ " City, in 2016. This is nonexperimental research. Data collected retrospectively and was analized descriptively. Samplestaken by purposive sampling method which searched the medical report of toddler patient suffer pneumonia hospitalized in RSUD "Y”X City, in 2016 which met the inclusion criteria. Reseach accuracy was analized used "Pedoman Pelayanan Medis Ikatan Dokter Anak Indonesia year 2009" and "British National Formularium for Children 2011-2012”, Such as indication accuracy, precision medicine accuracy, patient accuracy and drug dose accuracy. The result of the research was found that in 49 toddler patient suffering pneumonia, the kind of antibiotic used was cefotaxime (89,80\%), Ampicillin (4,08\%), combination of cefotaxime + gentamicin (4,08\%) and ampicillin + gentamicin (2,04\%). Evaluation of accuracy of the use antibiotic $100 \%$ right in indication, precision medicine by $93,87 \%, 100 \%$ patient accuracy, and $10,20 \%$ drug dose accuracy.
\end{abstract}

Keywords: pneumonia, toddler, antibiotic, rational

\section{PENDAHULUAN}

Pneumonia adalah penyakit infeksi saluran pernapasan penyebab kematian utama pada balita didunia. Diperkirakan setiap tahun lebih dari 2 juta anak di bawah usia 5 tahun meninggal dunia karena pneumonia (Shah et al., 2012) sedangkan di Indonesia tahun 2007 angka kejadian pneumonia pada balita yaitu 
sebesar 15,5\% (Depkes RI, 2008). Di provinsi Jawa Tengah tahun 2014 penemuan kejadian penderita pneumonia pada balita yaitu sebesar $25,77 \%$ (Dinkes Jawa Tengah, 2015). Sementara pada tahun yang sama di kota Magelang angka kejadian penderita pneumonia pada balita sebesar 60,06\% dengan 509 kasus (Depkes Kota Magelang, 2014).

Pneumonia disebabkan oleh bakteri dan dapat diobati menggunakan antibiotik. Bakteri yang sering menyebabkan pneumonia pada anak yaitu Streptococcus pneumoniae (S. pneumoniae) (Elorriagaet al., 2016). Pemilihan dan penggunaan antibiotik harus rasional untuk menghindari resistensi bakteri. Dipilih antibiotik yang ampuh dan merupakan pilihan utama untuk mengatasi kuman penyebab pneumonia berdasarkan data biogram mikrobiologi 6-12 bulan terakhir. Peran farmasis dalam terapi pneumonia adalah menilai rasionalitas terapi antibiotic (Depkes RI, 2005).

Penelitian sebelumnya di RSUP diKlaten tahun 2014 tentang evaluasi penggunaan antibiotik pada pasien pneumonia anak yaitu sebanyak 52 pasien yang memenuhi kriteria inklusi, dari evaluasi penggunaan antibiotiknya didapatkan hasil yang memenuhi kriteria tepat pasien sejumlah 52 pasien $(100 \%)$, tepat indikasi sebanyak 52 pasien $(100 \%)$, tepat obat 52 pasien $(100 \%)$, tepat dosis $(3,85 \%)$ (Aurora, 2015). Perbedaan penelitian ini dibanding penelitian sebelumnya adalah tempat dan sampel yang digunakan dimana penelitian ini adalah balita.

\section{METODE PENELITIAN Jenis Penelitian}

Jenis penelitian ini yaitu non eksperimental dengan menggunakan analisis secara deskriptif. Pengumpulan data dilakukan secara retrospektif. Teknik yang digunakan purposive sampling yaitu menelusuri catatan rekam medik pasien balita penderita pneumonia di instalasi rawat inap RSUD "Y" dikota "X" yang memenuhi kriteria inklusi.

\section{Teknik Pengambilan Sampel}

Sampel penelitian yang diteliti adalah seluruh pasien balita penderita pneumonia di instalasi rawat inap RSUD "Y" dikota " $X$ " Tahun 2016, Sampel diambil dengan menelusuri catatan rekam medik pasien yang memenuhi kriteria inklusi dan eksklusi.

Kriteria inklusi pada penelitian ini adalah:

a. Pasien balita rawat inap.

b. Pasien yang didiagnosis pneumonia yang mendapat terapi antibiotik.

c. Data rekam medik pasien yang berisi identitas pasien (nomor rekam medik, usia, jenis kelamin dan berat badan), jenis antibiotik yang diberikan, frekuensi, dosis, durasi dan rute pemberian.

Kriteria eksklusi yaitu pasien juga didiagnosis infeksi selain pneumonia.

\section{Analisis Data}

Data dianalisis secara deskriptif untuk mengetahui kerasionalan penggunaan antibiotik berdasarkan Standar Pelayanan Kesehatan Anak di Rumah Sakit (IDAI, 2009), British National Formularium For Children 2011-2012 dan Modul Tatalaksana Standar Pneumonia (Kemenkes RI, 2010).

$\%$ tepat indikasi

$$
=\frac{\text { Jumlah kasus tepat indikasi }}{\text { Banyaknya kasus }} \times 100 \%
$$

$\%$ tepat pasien

$$
=\frac{\text { Jumlah kasus tepat pasien }}{\text { Banyaknya kasus }} \times 100 \%
$$

$\%$ tepat obat

$$
=\frac{\text { Jumlah kasus tepat obat }}{\text { Banyaknya kasus }} \times 100 \%
$$

$\%$ tepat dosis

$$
=\frac{\text { Jumlah kasus tepat dosis }}{\text { Banyaknya kasus }} \times 100 \%
$$

\section{HASIL DAN PEMBAHASAN}

Jumlah populasi pasien pneumonia balita di RSUD "Y" kota "X" pada tahun 2016 adalah sebanyak 117 pasien. Data populasi yang diambil meliputi data karakteristik pasien yang sesuai dengan inklusi penelitian (pasien balita yang menderita pneumonia, pasien yang mendapat terapi antibiotik, data rekam medik lengkap, dan di rawat inap). Sampel yang memenuhi kriteria dari 117 
Tabel 1. Karakteristik berdasarkan jenis kelamin dan umur pasien pneumonia balita di instalasi rawat inap RSUD "Y" di kota " $X$ " Tahun 2016

\begin{tabular}{llcc}
\hline & \multicolumn{1}{c}{ Karakteristik } & Frekuensi & Persentase $(\mathrm{n}=49)$ \\
\hline Jenis kelamin & Laki-Laki & 30 & $61,22 \%$ \\
\multirow{3}{*}{ Usia } & Perempuan & 19 & $38,78 \%$ \\
& BBL(0-30 hari) & 0 & $0 \%$ \\
& Bayi(1-24 bulan) & 41 & $83,67 \%$ \\
& Anak kecil (2-5 tahun) & 8 & $16,33 \%$ \\
\hline
\end{tabular}

BBL: Bayi baru lahir

Tabel 2. Karakteristik pasien berdasarkan gejala dan lamanya perawatan pada pasien pneumoniabalita di instalasi rawat inap RSUD "Y" di kota " $X$ " Tahun 2016

\begin{tabular}{llcc}
\hline & Keterangan & Frekuensi & Persentase $(\mathrm{n}=49)$ \\
\hline Gejala & Batuk & 41 & $83,67 \%$ \\
& Sesak nafas & 23 & $46,94 \%$ \\
& Demam & 25 & $51,02 \%$ \\
& Pilek & 18 & $36,73 \%$ \\
& Kejang & 14 & $28,57 \%$ \\
& Muntah & 15 & $30,61 \%$ \\
& Panas & 21 & $42,86 \%$ \\
& Lamanya perawatan & 39 & $79,59 \%$ \\
& 7-6 hari & 10 & $20,41 \%$ \\
\hline
\end{tabular}

pasien tersebut didapatkan 49 pasien. Sisanya 68 pasien tidak dianalisis karena data rekam medik tidak lengkap dan pasien dengan infeksi lain.

Kasus pneumonia pada pasien balita dengan jenis kelamin laki-laki yaitu sebanyak $61,22 \%$ sedangkan pada pasien dengan jenis kelamin perempuan yaitu sebanyak $38,78 \%$ (Tabel 1). Hal ini sejalan dengan penelitian terdahulu bahwa jumlah pasien anak laki-laki lebih banyak daripada perempuan (Bestari dan Karuniawati, 2019; Lima et al., 2016).

Berdasarkan Tabel 1, dapat dilihat bahwa kasus pneumonia pada pasien balita banyak terjadi pada usia bayi rentang 1-24 bulan yaitu $83,67 \%$. Sistem imun yang belum sempurna adalah faktor penyebabnya sehingga bayi dan balita rentan terkena penyakit pneumonia (Depkes RI, 2008). Selain itu banyaknya bayi yang terinfeksi dapat karena adanya transmisi dari ibu ke anak yang berhubungan pada saat proses persalinan dan adanya kontak fisik dari pasien yang terinfeksi (WHO, 2013).

Data pada Tabel 2 menunjukkan bahwa batuk $(83,67 \%)$ adalah gejala yang paling banyak terjadi pada pasien pneumonia balita. Gejala batuk merupakan tanda adanya gangguan pada saluran pernafasan yang diikuti dengan produksi sputum dan rasa nyeri, pada kasus pneumonia gejala batuk adalah sesuatu yang normal terjadi untuk membersihkan saluran pernafasan yang disebabkan adanya benda saing atau organisme yang mengganggu saluran pernafasan. Lama perawatan inap di rumah sakit terbanyak adalah rentang 1-6 hari yaitu sebanyak 39 pasien (Tabel 2) karena lama perawatan ini di pengaruhi oleh durasi pengobatannya. Kasus pneumonia ini yang sudah tepat menjalani perawatan inap 7-10 hari sebanyak 10 pasien $(20,41 \%)$ karena perawatan inap untuk penyakit pneumonia sebaiknya diberikan selama 7-10 hari (Ostapchuk et al., 2004).

Antibiotik adalah obat pilihan utama untuk terapi penyakit pneumonia karena sebagian besar penyebab pneumonia yang paling sering menyerang anak adalah bakteri Streptococcus pneumoniae (Ostapchuk et al., 2004). Penggunaan antibiotik yang yang rasional dapat meningkatkan efek terapeutik klinis, mencegah toksisitas obat, meminimalkan terjadinya resistensi bakteri dan menurunkan biaya pengobatan 
Tabel 3. Jenis antibiotik yang dipakai untuk terapi pneumonia balita di instalasi rawat inap RSUD

\begin{tabular}{ccc}
\multicolumn{3}{c}{ "Y" di kota "X" tahun 2016 } \\
\hline Antibiotik & Jumlah & Persentase (n=49) \\
\hline Cefotaxime & 44 & $89,80 \%$ \\
Ampisillin & 2 & $4,08 \%$ \\
Cefotaxime + gentamicin & 2 & $4,08 \%$ \\
Ampisillin + gentamicin & 1 & $2,04 \%$ \\
\hline
\end{tabular}

Tabel 4. Penggunaan obat non antibiotik pada pasien pneumonia balita rawat inap di RSUD "Y" di

\begin{tabular}{|c|c|c|c|c|}
\hline \multicolumn{5}{|c|}{ kota "X" tahun 2016} \\
\hline No & Golongan & Nama obat & Jumlah & Presentase $(n=49)$ \\
\hline 1 & $\begin{array}{l}\text { Analgetik, } \\
\text { antipiretik }\end{array}$ & $\begin{array}{l}\text { Paracetamol/ proxion } \\
\text { drop® }\end{array}$ & 42 & $85,71 \%$ \\
\hline \multirow[t]{2}{*}{2} & Kortikosteroid & Dexametason & 5 & $10,20 \%$ \\
\hline & & $\begin{array}{l}\text { Betamethasone } ® / \\
\text { proceles } \AA\end{array}$ & 7 & $14,29 \%$ \\
\hline 3 & Bronkodilator & $\begin{array}{l}\text { Lasal syr®/ } \\
\text { salbutamolsulfat/ } \\
\text { nebu ventolin }\end{array}$ & 36 & $73,47 \%$ \\
\hline 4 & Mucolitik & $\begin{array}{l}\text { Ambroxol/mucos }{ }^{\circledR} \\
/ \text { mucera }{ }^{\circledR}\end{array}$ & 31 & $63,27 \%$ \\
\hline \multirow[t]{2}{*}{5} & Antiemetik & Ondasentron $₫ /$ narfoz $\AA$ & 3 & $6,12 \%$ \\
\hline & & Donperidon & 2 & $4,08 \%$ \\
\hline \multirow[t]{2}{*}{6} & $\begin{array}{l}\text { Vitamin dan } \\
\text { suplemen }\end{array}$ & Alcana & 3 & $6,12 \%$ \\
\hline & & Zink & 1 & $2,04 \%$ \\
\hline 7 & Antialergi & Cetirizine & 7 & $14,29 \%$ \\
\hline 8 & $\begin{array}{l}\text { Hipnotik dan } \\
\text { Sedatif }\end{array}$ & Sibital $® /$ Phenobarbital & 4 & $8,16 \%$ \\
\hline 9 & Antikonvulsan & Diazepam & 7 & $14,29 \%$ \\
\hline 10 & Dekongestan & $\begin{array}{l}\text { Rhinos neo®/ Rhinofed } ® / \\
\text { pseudoephedrin }\end{array}$ & 12 & $24,49 \%$ \\
\hline
\end{tabular}

(Kemenkes RI,2011 ${ }^{\mathrm{b}}$ ). Penggunaan antibiotik pasien balita penderita pneumonia di rawat inap RSUD "Y" dikota "X" dapat dilihat pada Tabel 3 .

Pada Tabel 3, menunjukkan bahwa antibiotik yang paling sering dipakai untuk terapi pneumonia balita adalah cefotaxime sebanyak 44 kasus $(89,80 \%)$. Cefotaxime adalah antibiotik golongan cefalosporin generasi ke tiga, digunakan sebagai terapi empirik yang diresepkan untuk bayi dan anak penderita pneumonia dan dirawat di rumah sakit serta pilihan obat antibiotik untuk pasien yang telah resisten terhadap penisillin (Bradley et al., 2011). Bila pengobatan secara empiris tidak ada perbaikan atau memburuk maka pengobatan disesuaikan dengan bakteri penyebab dan uji sensitiviti (PDPI, 2003). Penggunaan antibiotik dalam bentuk kombinasi keuntungannya dapat meningkatkan aktivitas antibiotik pada infeksi spesifik dan mengurangi resiko resistensi bakteri (Kemenkes RI,2011 ${ }^{\mathrm{a}}$ ).

Penggunaan obat non antibiotik biasanya diberikan pada pasien pneumonia sebagai terapi supportif. Tujuannya yaitu untuk mengurangi gejala atau keluhan pada pasien. Penggunaan non antibiotik dapat dilihat pada Tabel 4.

Pada Tabel 4 menunjukkan bahwa penggunaan non antibiotik sebagai terapi pendukung untuk pasien pneumonia paling 
Tabel 5. ketepatan obat antibiotik pada pasien pneumonia balita rawat inap di RSUD "Y" di Kota "X" tahun 2016

\begin{tabular}{|c|c|c|c|c|c|c|}
\hline \multirow[b]{2}{*}{ Antibiotik } & \multirow[b]{2}{*}{ Rute } & \multirow[b]{2}{*}{ Jumlah } & \multirow{2}{*}{$\begin{array}{l}\text { Persentase } \\
\quad(n=49)\end{array}$} & \multicolumn{2}{|c|}{ Ketepatan obat } & \multirow{2}{*}{$\begin{array}{c}\text { Alasan } \\
\text { ketidak tepatan }\end{array}$} \\
\hline & & & & Tepat & $\begin{array}{c}\text { Tidak } \\
\text { tepat }\end{array}$ & \\
\hline Cefotaxime & IV & 44 & $89,80 \%$ & $\sqrt{ }$ & - & - \\
\hline Ampisillin & IV & 2 & $4,08 \%$ & $\sqrt{ }$ & - & - \\
\hline $\begin{array}{c}\text { Cefotaxime + } \\
\text { gentamicin }\end{array}$ & IV & 2 & $4,08 \%$ & & $\sqrt{ }$ & $\begin{array}{c}\text { Gentamicin } \\
\text { seharusnya } \\
\text { dikombinasi } \\
\text { dengan ampisillin }\end{array}$ \\
\hline $\begin{array}{l}\text { Ampisillin + } \\
\text { gentamicin }\end{array}$ & IV & 1 & $2,04 \%$ & - & $\sqrt{ }$ & $\begin{array}{c}\text { Kombinasi } \\
\text { tersebut diberikan } \\
\text { untuk umur }<2 \\
\text { bulan (IDAI, } \\
2009 \text { ) }\end{array}$ \\
\hline
\end{tabular}

banyak yaitu obat analgesik-antipiretik sebesar 42 kasus $(85,71 \%)$. Pemberian terapi analgesik-antipiretik bertujuan sebagai pereda demam ( $\mathrm{suhu}>38,5^{\circ} \mathrm{C}$ ) sehingga suhu tubuh pasien dapat turun dengan pemberian paracetamol (Harris et al., 2011). Demam sangat umum terjadi pada orang yang menderita infeksi saluran pernafasan akut (Modul Tatalaksana Standar Pneumonia, 2012).

Tepat indikasi adalah kesesuaian pemberian antibiotik dengan indikasi atau gejala dan adanya diagnosa pneumonia. Seluruh pasien $(100 \%)$ tepat indikasi. Antibiotik yang digunakan pada terapi pneumonia balita di instalasi rawat inap RSUD "Y" dikota "X" tahun 2016 yaitu cefotaxime; cefotaxime+gentamicin; Ampisillin; Ampisillin + gentamicin.

Tepat obat adalah pemilihan antibiotik yang diberikan kepada pasien penderita pneumonia balita yang merupakan drug of choice sesuai dengan Pedoman Pelayanan Medis Ikatan Dokter Anak Indonesia dan British Nasional Formularium for Children 2011-2012. Berikut ini adalah data ketepatan obat antibiotik pada pasien pneumonia balita rawat inap di RSUD "Y" di Kota "X" tahun 2016.
Berdasarkan Tabel 5, menunjukkan bahwa analisa ketepatan penggunaan obat antibiotik pada pasien pneumonia balita sebanyak 44 pasien $(89,87 \%)$ tepat obat, karena sudah sesuai dengan acuan yang digunakan yaitu Pedoman Pelayanan Medis Ikatan Dokter anak Indonesia tahun 2009 dan British National Formularium For Children 2011-2012, yang menyebutkan bahwa antibiotik ampisillin dan cefotaxime adalah obat untuk pasien pneumonia anak yang diberikan secara intravena, antibiotik ampisillin dianjurkan untuk terapi empirik pada anak (IDAI, 2009) Serta gentamisin (tunggal) adalah antibiotik yang dianjurkan untuk terapi pneumonia anak umur (1bulan 18 tahun) (BNF for Children, 2011-2012). Sedangkan ketidaktepatan obat sebanyak 3 pasien $(6,12 \%)$ pada kasus tersebut yaitu penggunaan kombinasi antibiotik (gentamicin + cefotaxim), penggunaan kombinasi gentamisin seharusnya dikombinasi dengan ampisillin (IDAI, 2009) dan kasus tersebut bentuk kombinasi antara (ampisillin + gentamisin) yang seharunya diberikan untuk usia $<2$ bulan tetapi pada kasus ini diberikan untuk usia 10 bulan (IDAI, 2009).

Tepat pasien adalah ketepatan pemilihan obat yang sesuai dengan kondisi patologis dan fisiologis dan tidak kontraindikasi terhadap 
Tabel 6. Kontraindikasi penggunaan antibiotik pada pasien pneumonia balita (BNF Children, 2011-

\begin{tabular}{cccc}
\multicolumn{3}{c}{ 2012) } & \\
\hline Kontraindikasi & Cefotaxime & Gentamisin & Ampicillin \\
& Hipersensitifitas terhadap & Myasthenia gravis & Hipersensitifitas \\
& Shepalosporin & & terhadap \\
& & & Penicillin \\
\hline
\end{tabular}

Tabel 7. Data ketepatan antibiotik pasien balita penderita pneumonia balita

\begin{tabular}{|c|c|c|c|c|}
\hline \multirow{2}{*}{ Antibiotik } & \multirow{2}{*}{ Jumlah } & \multicolumn{2}{|c|}{ Keterangan } & \multirow{2}{*}{ Alasan ketidak tepatan } \\
\hline & & Tepat & Tidak tepat & \\
\hline Cefotaxime & 44 & $\sqrt{ }$ & - & - \\
\hline Ampisillin & 2 & $\sqrt{ }$ & - & - \\
\hline $\begin{array}{c}\text { Cefotaxime + } \\
\text { gentamicin }\end{array}$ & 2 & $\sqrt{ }$ & - & - \\
\hline $\begin{array}{l}\text { Ampisillin + } \\
\text { gentamicin }\end{array}$ & 1 & $\sqrt{ }$ & - & - \\
\hline
\end{tabular}

pasien (Depkes RI, 2008). Kontraindikasi dari antibiotik yang digunakan sebagai pengobatan pneumonia balita dapat dilihat pada Tabel 6 dan 7.

Hasil ketepatan pasien sebanyak 49 pasien $(100 \%)$ penggunaan antibiotik tersebut tepat pasien karena tidak ada kontraindikasi dengan keadaan pasien. Penggunaan antibiotik golongan sefalosporin yang diberikan yaitu cefotaxime, cefotaxime tidak kontraindikasi terhadap kondisi pasien karena pasien tidak mengalami hipersensitifitas terhadap sefalosporin dan pada golongan penicillin yang diberikan adalah ampicillin, ampicillin tidak kontraindikasi karena pasien tidak mengalami hipersensitifitas terhadap penicillin, sedangkan pada pemberian gentamisin juga tidak menimbulkan kontraindikasi terhadap pasien karena pasien tidak mengalami Myasthenia gravis.(BNF Children, 2011-2012).

Tepat dosis adalah ketepatan pemberian antibiotik sesuai dengan besarnya dosis, rute, frekuensi dan durasi pemberian. Dikatakan tepat apabila telah sesuai dengan Pedoman Pelayanan Medis Ikatan Dokter Anak Indonesia tahun 2009, British National Formularium for Children 2011-2012 dan Drug Information Handbook tahun 2009. Apabila dosis yang di pakai kurang atau lebih dari dosis yang dianjurkan maka dapat dikatakan pasien diberikan obat tidak tepat dosis. Ketepatan dosis pemberian antibiotik pada balita penderita pneumonia di instalasi rawat inap RSUD "Y" dikota " $X$ " tahun 2016 dapat dilihat pada Tabel 8.

Berdasarkan Tabel 8, penggunaan antibiotik yang tepat dosis adalah ketepatan pemberian antibiotik sesuai dengan besarnya dosis, rute, frekuensi dan durasi pemberian yaitu sebanyak 5 pasien $(10,20 \%)$ tepat dosis dengan nomer kasus 5, 8, 25, 41 dan 43 dari total 49 pasien. Ketidaktepatan dosis karena besaran dosis berlebih sebanyak 5 kasus $(10,20 \%)$, frekuensi berlebih 1 kasus $(2,04 \%)$, besaran dosis kurang sebanyak 37 kasus $(75,51 \%)$ dan frekuensi kurang sebanyak 3 kasus dengan persentase $6,12 \%$ (Tabel8). Ketidaktepatan pemberian antibiotik dapat mengakibatkan penyakit tidak sembuh, resiko meningkatnya efek samping, resistensi bakteri dan dapat meningkatkan biaya pengobatan (Nurmala et al., 2015).

Pemberian terapi antibiotik sebanyak 49 pasien $(100 \%)$ melalui rute intravena. Rute pemberian obat yang telah diberikan untuk antibiotik cefotaxime; Ampisillin; Cefotaxime + gentamicin dan Ampisillin + gentamicinsecara intravena telah sesuai dengan Pedoman Pelayanan Medis Ikatan Dokter Anak Indonesia tahun 2009 dan British National Formularium for Children 2011-2012 yang merekomendasikan untuk 
Tabel 8. ketepatan dosis pemberian antibiotik pada pasien pneumonia balita rawat inap di RSUD "Y" di kota "X" tahun 2016

\begin{tabular}{|c|c|c|c|c|c|}
\hline No & Kategori & Keterangan & No.kasus & Jumlah & $\begin{array}{c}\text { Persentase } \\
(\mathrm{N}=49)\end{array}$ \\
\hline \multirow[t]{2}{*}{1} & Besaran & lebih & $13,16,33,44,48$ & 5 & $10,20 \%$ \\
\hline & & kurang & $\begin{array}{l}1,2,3,4,6,7,9,11,12,14,15,18,19,21, \\
22,23,24,26,27,28,29,30,31,32,34, \\
35,36,37,38,39,40,42,45,46,49,10,33\end{array}$ & 37 & $75,51 \%$ \\
\hline 2 & Rute & IV & $1-49$ & 49 & $100 \%$ \\
\hline \multirow[t]{2}{*}{3} & Frekuensi & lebih & 40 & 1 & $2,04 \%$ \\
\hline & & kurang & $13,16,33$ & 3 & $6,12 \%$ \\
\hline \multirow[t]{8}{*}{4} & Durasi & 2 hari & $6,11,20,42$ & 4 & $8,16 \%$ \\
\hline & & 3 hari & $3,4,18,19,21,29,37$ & 7 & $14,29 \%$ \\
\hline & & 4 hari & $2,7,13,14,17,23,28,31,34,36,44,45,48$ & 13 & $26,53 \%$ \\
\hline & & 5 hari & $1,5,8,9,12,24,25,26,30,33,35,40,41,43$ & 14 & $28,57 \%$ \\
\hline & & 6 hari & $10,15,22,27,38,39,49$ & 7 & $14,28 \%$ \\
\hline & & 7 hari & 46,47 & 2 & $4,08 \%$ \\
\hline & & 8 hari & 16 & 1 & $2,04 \%$ \\
\hline & & 10 hari & 32 & 1 & $2,04 \%$ \\
\hline 5 & Tepat dosis & Tepat & $5,8,25,41,43$ & 5 & $10,20 \%$ \\
\hline
\end{tabular}

diberikan secara intravena pada pasien pneumonia balita.

Durasi pemakaian antibiotik dipengaruhi oleh keadaan pasien karena apabila pengobatan secara empiris tidak ada perbaikan atau memburuk maka pemberian antibiotik disesuaikan dengan bakteri penyebab serta uji sensitivitas dan apabila pasien membaik maka terapi empiris dilanjutkan (PDPI, 2003). Durasi pemakaian antibiotik pada pneumonia balita di instalasi rawat inap RSUD "Y" di kota "X" tahun 2016 dapat dilihat pada Tabel 8. Berdasarkan pedoman Modul Tatalaksana Standar Pneumonia (kemenkes RI, 2010) disebutkan bahwa durasi pemakaian antibiotik untuk pneumonia anak yaitu selama 5 hari, jadi berdasarkan pada Tabel8 durasi pemakaian antibiotik yang sesuai dengan pedoman Modul Tatalaksana Standar Pneumonia yaitu sebanyak 14 pasien dengan presentase $28,57 \%$.

\section{KESIMPULAN}

Berdasarkan hasil penelitian yang dilakukan terhadap 49 pasien pneumonia yang telah memenuhuhi kriteria inklusi di instalasi rawat inap RSUD "Y" di Kota "X" tahun 2016 dapat disimpulkan bahwa jenis antibiotik yang digunakan adalah Cefotaxime (89,80\%), Ampisillin (4,08\%), Kombinasi Cefotaxime + gentamicin $(4,08 \%)$ dan Ampisillin + gentamicin (2,04\%). Dari hasil evaluasi penggunaan antibiotik didapatkan $100 \%$ tepat indikasi; $93,87 \%$ tepat obat; $100 \%$ tepat pasien dan $10,20 \%$ tepat dosis.

\section{Daftar Pustaka}

Aurora, A.T., 2015. Evaluasi Ketepatan Antibiotik Pada Pasien Anak Terdiagnosa Pneumonia di RSUP Dr. Soeradji Tirtonegoro Klaten Tahun 2014 (Skripsi, Universitas Muhammadiyah Surakarta, Surakarta.

BMJ, 2011. BNF for Children 2011-2012, BMJ Group, Pharmaceutical Press, and RCPCH Publications Ltd, London. 
Bradley J.S., Byington C.L., Shah S.S., Alverson B., Carter E.R., Harrison C., Kaplan S.L., Mace S.E., Jr G.H.M., Moore M.R., Peter S.D.S., StockwellJ.A. and Swanson J.T., 2011, The Management of Community-AcquiredPneumonia in Infants and Children Older Than 3 Months of Age: ClinicalPractice Guidelines by the Pediatric Infectious Diseases Society and the Infectious Diseases Society of America, Clinical Infectious Diseases, 152.

Bestari, M.P., Karuniawati, H., 2019. Evaluasi Rasionalitas dan Efektifitas Penggunaan Antibiotik pada Pasien Pneumonia Pediatrik di Instalasi Rawat Inap Rumah Sakit Pusat Jawa Tengah. Pharmacon: Jurnal Farmasi Indonesia 14, 62-71-71. https://doi.org/10.23917/pharmacon.v14i2.6524

Depkes Kota Magelang, 2014. Profil Kesehatan Kota Magelang Tahun 2014, Magelang, Dinkes Kota Magelang.

Depkes RI, 2008. Profil Kesehatan Indonesia, Jakarta, Depkes RI.

Dinkes Jawa Tengah, 2015. Profil Kesehatan Provinsi Jawa Tengah Tahun 2014, Semarang, Dinkes Provinsi Jawa Tengah.

Elorriaga, G.G. dan Del Rey-Pineda G., 2016. Basic Concepts on Community-Acquired Bacterial Pneumonia in Pediatrics, Pediatric Infectious Diseases: Open Access, Vol.1 No.1:3.

Gangil, J., Adhikari P., Sam K.G., Kumar A., Girish, Sanal, T.S., 2010. Evaluation of Azitromycin as add On Therapy in Community Acquired Pneumonia Patients: A Pilot Clinical Study, Journal of CurrentPharmaceutical Reasearch, 2(1), 15-20.

Harris M., Clark J., Coote N., Fletcher P., Harnden A., McKean M. and ThomsonA., 2011. Guidelines for the management of community acquired pneumoniain children: update 2011, BMJ Group, 66, 1-26.

IDAI, 2009. Pedoman Pelayanan Medis, Jakarta, IDAI.

Kemenkes RI, 2010. Modul Tatalaksana Standar Pneumonia, Jakarta, Kemenkes RI.

Kemenkes RI, 2011 a . Buku Panduan Hari Kesehatan Sedunia. Keputusan Menteri Kesehatan Tentang Standar Pelayanan Farmasi di Rumah Sakit. 2004. No 1197/MENKES/SK/X/2004.

Kemenkes RI, 2011 ${ }^{\mathrm{b}}$,Pedoman Pelayanan Kefarmasian Untuk Terapi Antibiotik, Jakarta, Direktorat Jendral Bina Kefarmasian dan Alat Kesehatan.

Lima, E.J. da F., Mello, M.J.G., Albuquerque, M. de F.P.M. de, Lopes, M.I.L., Serra, G.H.C., Lima, D.E.P., Correia, J.B., 2016. Risk factors for community-acquired pneumonia in children under five years of age in the post-pneumococcal conjugate vaccine era in Brazil: a case control study. BMC Pediatr 16, 1-9. https://doi.org/10.1186/s12887-0160695-6 
Nurmala, Virgiandhy I.G.N, Adriani, Delima F, Liana, 2015. Resistensi danSensitivitas Bakteri terhadap Antibiotik di RSU dr. Soedarso Pontianak tahun2011-2013, Resistensi dan Sensitivitas Bakteri, Vol. 3, No. 1, halaman 21-27.

Ostapchuk M., Roberts D.M. and Haddy R., 2004. Community-Acquired Pneumonia in Infants and Children, American Family Physician, 70 (5),1-10.

PDPI, 2003. Pedoman Diagnosis dan Penatalaksanaan Pneumonia Komunitas di Indonesia, Jakarta: Perhimpunan Dokter Paru Indonesia.

Shah, G.S., Dutta, A.K., Shah, D., Mishra, O.P., 2012. Role of zinc in severe pneumonia: a randomized double bind placebo controlled study. Ital J Pediatr 38, 36. https://doi.org/10.1186/1824-7288-38-36

WHO, 2013. Pocket Book On Hospital Care for Children Guidlines for The Management of Common Childhood Illnesses, Second Edition. WHO Press, Switzerland 